\title{
Ways to Increase Effectiveness of Managerial Staff Training in the Sphere of Public and Municipal Administration
}

\author{
Asya Efimovna Eroyan ${ }^{1}$ \\ Natalya Vladimirovna Andreeva1 \\ Elena Anatolievna Gorlova ${ }^{1}$ \\ Tigran Levonovich Oganesyan ${ }^{1}$ \\ Levon Levonovich Oganesyan² \\ ${ }^{1}$ Kuban State Technological University \\ 2Southern Managerial Institute \\ Email: aru-asya@yandex.ru,nazarkina@mail.ru,oganesyant@mail.ru, marli5@rambler.ru
}

Doi:10.5901/mjss.2015.v6n3s6p321

\section{Abstract}

This Article features the specifics of public employees training in Russia as well as analyses some key issues and tasks on how to achieve higher professional levels among state and municipal employees. It depends on a civil servant how stable is the operation of enterprises, institutions and organizations, and, therefore, how decent is the standard of living of citizens in the modern environment. This is why we see it as one of the top priorities of the public service institution to be even more effective the implementation of its economic and social functions, such as government regulation of the economy. Thereby, the professional training of public servants in the Russian Federation is an issue of a very high importance. Today, there is a strong need to readjust the requirements and values in the sphere of civil servants training in this country. Why is it so that the qualification of civil servants has such an important role in the economic and political spheres of this country? Because it is exactly from the above effort that the right moral and professional orientation starts, which is indispensable to perform public duties in a proper manner. The results of this analyses can be used to develop such required programs for adjustment training courses and skill upgrading of public officials at all levels of administration.

Keywords: Public and municipal service, civil servants training, skill upgrading and improvement, effectiveness and efficiency, educational process and training.

\section{Introduction}

All of the life spheres are developing very fast and demanding a special attention from the social and economic development programs throughout all of the regions of this country. However, even today, there is an acute shortage of qualified professionals for the development of all of the industries. The international experience shows that the vocational education and training is required for future employees as an essential prerequisite for successful operation of every enterprise.

Today, about $70 \%$ of Russian professional staff members are lacking elementary vocational education. Especially the regions of this country suffer from such lack of professionals in their industries.

Therefore, there is a need to educate new generation of professionals, who acquire ingenuity, extensive knowledge and skills in related areas apart from the main ones. The main goal is to ensure that the graduates are qualified professionals having appropriate professional knowledge and integrity of their moral and psychological qualities. Such criteria has to be applied when making decision on whether such professionals areeligible to work in the chosen field. Life always proves that the saying "Staff are a key to everything" seems to be quite right Nechiporenko, V.S. (2008).

\section{Methodological Aspects of Studying}

With every passing day, the main burden in the implementation of the country's reforms is becoming more and more a responsibility borne by regional administrations and governments, including local self-governing bodies (LSG). In this 
country, the processes of decentralization and regionalization are becoming more and more intensive these days. Public Service of Constituent Members of the Russian Federation along with municipal services have no other option but exercise powers vested by federal institutions. In this regard, the task of preparing qualified staff within the appropriate region and local government authority is becoming a key-importance matter.

It is not possible to perform the restructuring of region economies without implementing effective managerial tools to develop staff potential and to employ scientific methodological research work in order to provide such territorial institutions with the required well-trained professional staff. Today, we are witnessing the formation of new territorial governing and local self-administering institutions in the administrative areas under the responsibility of the Russian Federation Constituent Members. Such new organizations are supposed to be oriented to a real and sustainable growth of their population living standards Gafiyatullina, K.R. (2013).

All of the above work is being materialized considering the following existing factors:

- specific and personalized staff policy, which is pursued by the leaders of Constituent Members of the Russian Federation or the administrators of local self-governing bodies, who came into power by uncompromising struggles;

- growing contradictions between the increase of the number of administrators (versus the resources spent for their preparation and material support) and the final socio-economical results out of their activity;

- deepening disproportion between the goals of the reforms and the human resources utilization degree;

- disparity between staff professional qualification dynamics and the new functions of the administration system as well as the objectives and rhythms of the development of the regions and municipalities.

The problem of staff professionalism of the public and municipal services is quite significant today due to rather high speed that the changes occur in all of the industries. The decision-makers should be professional public and municipal servants to ensure that managerial decisions are taken in a timely manner and considering the society's needs. This means that apart from being able simply to adjust to new realities, they have to be able to build their own style of behavior and to change the situation in order to achieve the best results out of their professional activity.

The reforms that are under implementation process in this country cannot but influence administrative authority itself. The peculiarities of the Russian statehood development over the recent decade impose that the main attention is focused on the matter of training and qualification improvement of the administrative staff. In this sphere, there is a need to use radical measures and optimize public and municipal administration systems. However, some negative factors, such as lack of openness, authoritarianism of the Russian administrative system, oppose to its reforming processes. Until now, in Russia the selection and rotation of the staff within the public and municipal administrations has been carried out on protectionism basis. The situation the country faces is that the graduates from higher educational establishments, even, having diplomas with honors, cannot get a job with public authorities under the pretext that they are lacking the required work experience. At the same time, many of the public and municipal servants do not have appropriate vocational education. This situation leads to a conclusion that the system of professional education, additional refresher training and skill improvement programs, as they are now, is far from being perfect and do not meet the requirements of today's modern society.

The traditional education system mainly uses outdated teaching techniques, and despite of the fact that many students do get strong theoretical fundamentals, their practical education does not seem effective enough in most of the cases. Therefore, Russian universities and other educational establishments prepare a large number of professionals but they are not able to work for public and municipal bodies due to the fact that their personal, professional qualities and communication skills are not sufficient, though they get large fundamental knowledge in such disciplines as law, economy, and political aspects. Hence, the system of higher professional education, which is involved in preparing public and municipal servants, has to be able to generate new educational process techniques, and adjust immediately to the international education standards considering market requirements as well.

Nowadays, it is required that public and municipal servants are not only disciplined and diligent people but also they are highly qualified, ambitious and able to quickly and correctly solve problems of various degrees of complexity. They are also supposed to react timely on new situations and norms, operate effectively in the changing environment. Due to the above, the preparation of the public officials for such caliber becomes an issue of the state level. Today, public servants should have knowledge and skills to solve problematic matters of economical, legal, political nature etc. Gafiyatullina, K.R. (2013).

It is of common knowledge that today the training of the public servants is effectuated by the following educational areas:

1. training in higher education establishments (first higher education degree);

2. qualification improvement in higher education establishments; 
3. various internship training courses;

4. additional and refresher courses;

5. specialized training courses, conferences, seminars. Gafiyatullina, K.R. (2013)

Additional and refresher courses as well as qualification improvement training of the servants have to ensure high level of professional knowledge and skills for public and municipal servants, aiming to prepare them for performing new functional duties.

The main principles for qualification improvement and professional additional training imply that such courses are obligatory, frequent and target oriented.

Professional additional training is supposed to teach public and municipal servants, who have higher professional education, ensuring they get additional knowledge and skills, that they need to perform a new type of professional activity. Such training enables them to get additional qualification based on the qualification they already have.

Professional qualification improvement refers to a continuous training of public and municipal servants in order to refresh their theoretical and practical knowledge when the requirements to qualification level increase and/or the servants have to learn new methods for performing professional duties.

Internship as an independent type of additional professional education enables public servants to:

- deepen their professional knowledge and skills, they have got as the result of theoretical preparation, and improve such knowledge and skills on practical grounds;

- familiarize with best practices and advanced experiences;

- acquire skills in performing their duties on appropriate positions (Presidential Degree dated 28/12/2006 No. 1474 "On Additional Professional Education of Public Civil Servants of the Russian Federation).

Main objectives of professional level improvement for public and municipal servants mean that:

- public servants get a sense of responsibility for their actions, striving for continuous improvement of their professionalism according to the specifics of their activity in an appropriate area of responsibility;

- public and municipal service routine practice is enriched with new scientific achievements, innovative working techniques as well as with scientific organization of labor activity;

- completely new knowledge appears in the sphere of public and municipal administering;

- accomplishment of service tasks and duties becomes more successful and timely by developing and mastering the most efficient and systematic activities;

- public servants learn the techniques to ensure safety in cases of emergency and in extreme conditions, maintain the staff in permanent readiness to act decisively and competently in emergency situations;

- the qualified staff of the public and municipal administration is being formed and maintained to achieve the goals of the country in the development of the state, region and municipalities in accordance with modern requirements to managerial activity;

- practical skills of elaboration and application of legal norms are being constantly improved in order to manage social relations and ensure law and order;

- professional and psychological qualities are being formed and developed;

- $\quad$ skills to work with information systems and to use information technologies are being developed;

- existing managerial tools are being optimized and enlarged;

- local population is involved in public and municipal management.

From education guidelines point of view there are two main models for training specialists in the sphere of public and municipal administration. Each of the models in reference uses its particular vision as to appropriate qualification.

The first model is an «American» one, which treats a public servant as an administrator. Accordingly, curricula for teaching them give the priority to political and administrative disciplines as scientific fundamentals for decision making in the public sector. In the USA the control and monitoring of the quality of education is performed by professional organizations that ensure decentralization of the training system for public servants. Financing for preparation of public administrators is obtained from various sources: both private and government. In general, the system of professional education of administrators meets the requirements of public and municipal administration, because the majority of the American administrators pass intra-departmental preparation.

The content of the curricula is being determined based on expert surveys, as well as the referential list of duties and objectives that public servants have to reach as the result of performing their duties. In the result some scope clusters are composed and further used when elaborating curricula and determining timeframes for teaching.

The second one is a «European Continental» model, which assumes that the public servant is a materializer of the decisions taken by higher-ranking authorities. The main task of a servant in this option is to interpret and materialize the decision in the strict compliance with the legislation in force. It is obvious that this model requires that a public servanthas 
to have law educational background as a basic higher education Zvereva, S.A. (2006).

For example, in Germany it is required that a public servant has appropriate professional education and specialized preparatory training, which should not be very specialized to work for public services. The main task when preparing specialists to work for public services is to teach them fundamental tasks of the public service, their rights and powers required to perform their duties. A special attention is given to form high adaptability and communicative qualities as well as to develop a system thinking. Internships are encouraged. The continuing education is an important condition for such career building.

Training of administrative staff is an important component in transformational changes that take place in the public service of Great Britain. Development of abilities in administering the changes as well as improvement of leadership qualities have the direct positive influence over the quality of services to be rendered. This is the reason for modern public administration concepts materialization in Great Britain to determine appropriate changes in the curricula for public servant training. For example, it has been elaborated a «system of competency evaluation», which establishes requirements for public servants and demands continuous improvement of qualifications. Such approach is an incentive to gain new knowledge and skills, as well as to develop modern administration techniques. In the UK, there are two systems for public servants training which are used in parallel. They are: centralized and decentralized systems. The decentralized system consists in a large variety of seminars and teaching programs. Such activities are organized and effectuated by the ministries and departments. They use monitoring to know the needs in appropriate public servants and they program their future employment as well. Every structural unit, involved in such training programs, independently elaborates its own program for public administration staff and adjust such programs to the specifics of their organizational chart.

Due to globalization processes in a number of European countries and in the USA the public services are being reformed. The importance of such professional features as leadership qualities, skills to administer changes, ability for decision-making is constantly increasing. Undoubtedly, the system of staff training is changing in compliance with such new requirements.

It is quite interesting that the key elements for business employee training used to be openness for innovations and creative thinking. As far as public servants are concerned, they are mostly oriented for immediate and competent accomplishment of the decisions taken by a superior body. They are also supposed to meet established procedures, to have skills of implementing required procedures and accomplishing prescribed instructions. The initiative was normally not encouraged. Today such patterns are no longer acceptable because the effect of the decision made on such basis has worsened recently. Today, the effectiveness of the work of public and municipal servants depends on communicative skills, system thinking and self-determination. Such results can be achieved exclusively by developing inter disciplinary approach in public and municipal servant training.

Due to the fact that the market economy trends are integrating in the public structure the countries of Western Europe and the USA have come to a conclusion that it is indispensable to implement competition basis in the activity of public administrations.

Today, the level of qualification in Russia is composed of the first higher education in combination with the experience gained. Educational establishments in Russia, nowadays, such as the institute of public service sand the institute for qualified administrative staff training are at the stage of formation looking for effective techniques Patokina, O.A. \& Fedotov Yu.V. (2002).

Certainly, here in Russian, we apply for foreign experiences very frequently when trying to solve a number of problems. However, in every case we have to bear in mind that every nation has its distinctive features to be considered.

Federal and regional executive authorities as well as educational establishments have realized that it is indispensable to use a system approach to solve the staffing problem. Such approach, if simplified, has to respond to three key questions, such as: How much? Whom? How?

It is a common knowledge that in March 2009 it was adopted in Russia a Presidential Decree on Federal Program called «Reforming and Development of Public Service System of the Russian Federation for the years of 2009-2013» (Presidential Degree dated 10/03/2009 No. 261 "On the Federal Program 'Reforming and Developing Public Service System in the Russian Federation for the years of 2009-2013). One of the goals of that program document was «preparation of highly professional staff for public service to ensure effective public administration and development of civil society and innovative economy». More over, this document established such problem-solving tasks as:

- professional development of public servants based on modernized training programs;

- improvement of additional professional training system for preparation of public servants;

- implementationofmonitoringsystemaimedatcreatingpublicopinionaboutefficientfunctioningofthepublicservicein general, and effective professional service activity of individual public servants, in particular; 


\section{- $\quad$ among other tasks.}

That Federal Program describes expected results out of such efforts. For example, every structural unit of the public administration was meant to elaborate appropriate training programs and individual plans in order to ensure professional improvement of public servants. The intention was to use modern educational technologies in the process of training in a wide scale and get up dated all of the training programs including additional professional education curriculum for public servants. Unfortunately, the Program in reference does not specify tools for achieving the required goals Pronkin, S.B. (2005).

It is obvious that to create a professional public service it is indispensable to significantly improve the systems of public servant training including additional professional education. However, it is not quite clear who is supposed elaborate such systems and who is supposed to by a responsible entity for quality and relevance of educational technologies and techniques: public service institutions or higher educational establishments? The document in reference states that actual needs of public service should be considered as a fundamental for state educational standards both higher and secondary vocational educational establishments as far as public administration curriculum is concerned. Unfortunately, today we do not see any mechanism operating on day-to-day basis and ensuring coordination between public authorities and higher educational institutions in order to promote mutual exchange of experience both practical and theoretical. It is not possible elaborate modern educational standards and techniques without knowing the specifics of public service functioning, the powers and duties of the public servants and the problems they face in their activities. It is extremely important that in the every day changing global world environment Russian public service institutions be supposed to continue functioning in a stable and effective manner.

They should be able to adjust easily to external changes leaving behind that awkward bureaucratic machine that is fatally lagging behind increasing needs of the society. That is why there are serious handicaps on the way to federal program implementation in order to improve the activity of public servants. Such handicaps are not just originated by the functional specifics of the regional public institutions. It also happens because regional public institutions do not establish close relations with higher educational establishments.

The problem of public servants professional improvement is one of the major issues in the system of public and municipal service. It is generally acknowledged now that present servants of Russian public administration institutions today are not competent and professional enough. Some of the public officials do not possess sufficient experience, knowledge and skills in public service. Often times they do not have sufficient legal, socio-economic nor administrative preparation that is required to their service activity. In order to solve such mentioned problems in 2011 the Governor of the Krasnodar Region approved a Long-term Regional Target Program named as «Staffing System for Public Administration Institutions of the Krasnodar Region for the years 2012-2014» (Resolution of the Head of Administration of the Krasnodar Region dated 22/04/2011 No. 383 "On Approval of Long-Term Regional Target-Based Program 'The Staffing System for Public Administration Institutions of the Krasnodar Region for the years 2012-2014). That program establishes many of the goals and tasks stipulated initially by the Federal Program mentioned above. However, this document stipulates very important new task: professional improvement of municipal servants - public representatives of the primary level. Enacting such regional program is one of the steps on the way towards solution of public staffing problem and preparation of public servants whose professional qualifications comply with reform requirements and who possess personal initiative in their activities and have appropriate specialized education. It is rather innovative factor that this document instructs that a targeted-program method should be used to solve professional improvement problem among the staff of Krasnodar region public administration institutions. Undoubtedly, the efficiency of socio-economic transformations depends on administrative and professional competency of public and municipal servants. The above factor cannot but have positive influence over the image of the authority, and it contributes significantly to favorable public.

Targeted programs aimed at activity improvement of public authority a tall levels of administration. Such programs also provide the tools required to improve qualitatively staff potential of the public and municipal services.

Even the most innovative educational techniques will hardly bring expected results unless the feedback communication is established between the public institutions and the society. The latter is supposed to provide evaluation of the activity of the public and municipal institutions. In this regard it is important to establish mechanisms of valuation and control of public servants apart from optimizing and improving training systems for public and municipal servants. Appropriate information is always required about the programs which are under implementation by public authorities to determine whether a particular authority and/or institution really serves the interests of the civil society. There the only way to organize effective public and municipal services o that it meets social interests. Such way is based on the development of civil relations in the country, mutual responsibility for the results both the public and municipal administration and the civil population Nechiporenko, V.S. (2008). 
There are some general problems in the Russian public servant education system that require immediate prioritized solution. Those areas follow:

1. insufficiency of funds for materialization of various targeted programs;

2. low usage of modern technologies to exchange practical experiences and to provide practical information; lack of teaching techniques and methodology to develop practical skills among other numerous problems.

There are also some problems in the sphere of education, training and selection of the public and municipal staff. Such problems affect efficiency of the public and municipal services and they are as follow:

1. In many cases, the professionally significant qualities of the public servants are not unconditional criterion when employing people for such positions.

2. Estimation and forecasting methods, which are applied in public and municipal service staffing, are not effective enough.

3. The tender rights for state-guaranteed contracts on professional additional training and qualification improvement courses for public servants are granted without competition basis between non-governmental and state educational institutions.

4. The initiative of higher educational establishments in the sphere of training, retraining etc, of the public and municipal servants is significantly limited by their dependence from the clients.

5. The Federal system of general and professional education, supervised by the Ministry of Education and Science of the Russian Federation, is not linked to the system of additional professional training of the public officials. This factor cannot but affect negatively the efficiency of their qualification improvement.

6. There is certain legal uncertainty and discontinuity of application of the majority of professional development principles in the sphere of public and municipal servant training. This factor stand store a son of low quality of legal support to professional training, retraining and qualification improvement of the public officials.

7. There are no clear perspectives for the creation of the system of higher educational establishments having competencies to efficiently train and retrain the public and municipal servants.

It is a common knowledge that there are serious claims to educational establishments involved in the public staff education. That is why we can not blame the graduates that their qualification does not match the required criteria.

First, nobody knows how many specialists this sphere of activity needs. Normally, such figure is supposed to consider both actual and future needs.

Second, the existing classification system does not allow determining clearly the list of positions and professions of the public servants, which is required from educational establishments to develop proper training of their students in particular aspects.

Third, it is important that public and municipal servants participate in the career building activities, which are developed by higher educational establishments in order to enable them to prepare high-level specialists for this particular sector. Such approach would enable educational institutions to select and attract the most motivated students, eager to work for public institutions.

Definitely, the qualification improvement-training sector is a very important component to increase professionalism of the public and municipal servants. However, in the reality, it is not quite easy to meet all the needs of public officials in qualification improvement due to limited timeframes and lack of financing. That is why it is extremely important that such components of real public administering activity is included in the curricula of the courses and innovative forms of education are used in a more effective manner, such as «round tables» and «master classes». By using imitation techniques, workshops, employing highly professional, reputable and practice-oriented instructors, by wider implementation of remote forms of training as the most promising we can significantly improve the process of such training.

Moreover, the task of professional preparation content improvement is being updated today. It is important to have individual approach towards selection of future students for various qualification improvement courses considering specific requirements of occupation and career opportunities.

\section{Concluding Remarks}

Flexibility, optimal combination of all type sand forms of general and professional educations, post-graduation and shortterm refresher training will definitely enable to achieve positive results in the process of preparation of staff for public services. Such approach will also enable to combine all of the forms of general and professional post-graduate education in the most efficient manner.

We see some significant problems that can be solved by following activities: 
1. Today it is determined in the standards that to lecture some specific disciplines the representatives of various public and municipal institutions should be invited. Too urmind such attitude will enable students to acquire real knowledge by practical case studies on one side, and on the other, it will give good opportunity to the potential employers to select appropriate people in the process of training to work on particular positions they need to fill.

2. In this country the quantitative structure of the public officials is really «exaggerated» ( In Germany, for instance, the percentage of public servants as compared with the working-age population is $15.1 \%$, in the USA - 15.5\%, in France - 22.6\%, in Japan - 8.1\%) Patokina, O.A. \& Fedotov Yu.V. (2002). Another solution to the problems could be to make redundant some positions to consider organizational charts, i.e. in cases of lack of competency some employees can be substituted for more experienced and competent ones.

3. Elaboration of qualification requirements for specific professions and creation of a special chapter, such as "Qualification Characteristics of the Employee's Positions» in the Unified Qualifications Handbook of Administrators, Professionals and Servants Pronkin, S.B. (2005).

4. Elaboration of professional standards for professions considering new approaches.

5. Elaboration of the staff certification system (staff qualification and competencies), which could be applied to all of the graduates of professional education and training.

6. Active usage of experience exchange opportunities with experienced and effective public servants by promoting 'round tables', conferences to be organized by higher educational establishments and where such public leaders will have the possibility to exchange their knowledge and experience with students in such spheres of activity.

7. An important role in the self-development of individuals has a professional orientation. The professional orientation contributes to continuous development of the employee considering his or her abilities. It is in dispensable to prepare an employee to continuously changing life conditions and professional activity standards.

The results of such measures have to become a fundamental for creation of new public administration training standards for higher professional education. Such preparation of the public administration staff will meet the requirements of the industry in particular and the country in general in the most adequate way.

Too urmind, it is exclusively the creation of a well-developed training structure considering advanced modern dem and sand its close cooperation with public and municipal institutions will ensure we get highly professional staff for this kind of activity. It will also be a fundamental for future success full development of this sector of activity and the country itself.

\section{References}

Presidential Degree dated 28/12/2006 No. 1474 "On Additional Professional Education of Public Civil Servants of the Russian Federation (as amended on 06/12/2007)

Presidential Degree dated 10/03/2009 No. 261 "On the Federal Program 'Reforming and Developing Public Service System in the Russian Federation for the years of 2009-2013.

Resolution of the Head of Administration of the Krasnodar Region dated 22/04/2011 No. 383 "On Approval of Long-Term Regional Target-Based Program 'The Staffing System for Public Administration Institutions of the Krasnodar Region for the years 20122014".

Gafiyatullina, K.R. (2013) Ways to Enhance the Effectiveness of Public Servants Training in the Russian Federation. Internet Magazine of Scientific Publications for Students and Young Generation Scientists "Economics, State, Society" (ESS). Issue No. 1 (12).

Zvereva, S.A. (2006) Problems of Municipal Servants Training At the Present Stage of Reforms//The Current Stage of Reforming of the Russian Public Administration System and Local Sel-Governing Authority: thesis, report, conference, Ekaterinburg, Urals Academy Of Public Administration.

Patokina, O.A. \& Fedotov Yu.V. (2002) Pattens for Public Servants Training. Problems of Education// VESTNIK of Saint Petersburg University No. 4. pp. 147-175.

Pronkin, S.B. (2005) Public Administration in Foreign Countries. Manual.' IS.B. Pronkin, O.E. Petrukhina - M., Aspect-Press. pp. 416.

Nechiporenko, V.S. (2008) Theory and Organization of Public Service. - M.: Publishing House RAGS (PAГC), 2008. pp. 160. 
